\title{
Nutrient Balances and Management of Soil Fertility Prior to the Arrival of Chemical Fertilizers in Andalusia, Southern Spain
}

\author{
Manuel González de Molina, a Roberto García-Ruiz, ${ }^{1 b}$ \\ David Soto Fernández, ${ }^{a}$ Gloria Guzmán Casado, a Antonio Cid, a \\ and Juan Infante Amate ${ }^{a}$ \\ a Department of Contemporary History \\ Pablo de Olavide University, Seville, Spain \\ b Department of Animal and Plant Biology and Ecology \\ University of Jaén, Spain
}

\section{Abstract}

Studies on the role of nutrient balances in the socioecological transition of agriculture are scarce, particularly in the Mediterranean region where manure availability was low. The role of nutrient balance in this transition was evaluated in three representative localities of the inland Mediterranean region of southern Spain from 1750 to 1900 . Changes in cropland distribution, population, manure availability and demand, and nutrient balance at cropland and aggregated scales were assessed. Data suggest that agriculture development around 1750 was limited by manpower. During this period manure availability was higher than demand and municipal balances for nitrogen were positive, whereas they were slightly negative for phosphorus and potassium. During the 19th century, the population increased while livestock numbers and manure availability decreased. Nutrient balances become negative at crop and aggregate scales, indicating that productivity was based on soil mining. This territorial imbalance and soil mining were the main reasons behind the turn-of-the-century crisis which led to the agrarian socioecological transition.

Keywords: nutrient balances, socioecological transition, soil fertility replenishment, historic organic agricultures

1 Corresponding author: rgarcia@ujaen.es. 


\section{Introduction}

Over the past two centuries, exceptional changes in the natural environment attributed to human activities have attached renewed importance to the study of society-nature interactions. The socioecological transition from a solar-based agriculture lacking in synthetic fertilizer to an industrial-based one fueled by synthetic fertilizer, breeding, pesticides, and machinery has been a topic frequently discussed by historians (Fischer-Kowalski \& Haberl, 2007; Krausmann, 2001, 2004; Krausmann et al., 2008; McNeill \& Winiwarter, 2006; Pfister, 1990; Sieferle, 2001; Smil, 2001). In fact, before the first quarter of the 20th century, European agriculture operated within a fundamentally different framework from that existing today. Before fossil fuels and appropriate technology became available to power agricultural machinery and synthesize mineral fertilizer, agriculture largely relied on input from human and animal labor, biomass, and sunlight (Pimentel \& Pimentel, 1996; Smil, 2008). Pre-industrial agriculture was potentially sustainable, but in practice there were several factors limiting sustainable agriculture in the long term. There is sufficient evidence to suggest that the degree of pre-industrial agricultural intensification was close to maximum because of the impossibility of soil fertility replacement. The preindustrial agriculture of the Great Plains is a paradigmatic case (Cunfer \& Krausmann, 2013) and the use of multiple strategies to increase input of organic sources of nutrients in northern Spain is an example of the search for soil fertility replacement possibilities (Tello et al., 2012).

In addition, many studies have highlighted the fact that current industrialized agriculture causes major environmental problems, leading to a new socioecological transition toward a more sustainable agriculture. The study of traditional agricultural systems based on organic fertilization could be a starting point and a useful tool for the optimum design of this transition. However, studies on the role of nutrient balance are scarce, despite the fact that the replenishment of soil fertility was a critical factor for the long-term stability of harvests. The replenishment of soil fertility must have been a key feature at the beginning of the socioecological transition toward industrialization. Most of the studies on this transition have been carried out in a western and northern European or North American context and have mainly analyzed changes in the distribution of cropland and crop intensification (i.e., productivity) and extensification relating to changes in population and distribution (Allen, 2008; Barles, 2007; Brassley, 2000; Campbell \& Overton, 1991; Cunfer, 2004, 2005; Shiel, 2006; Van Zanden, 1991).

This paper assesses the first steps of the soil fertility transition in the Mediterranean region, where agroecological conditions are extremely different to those of western and northern Europe. The possibilities for developing and 
specializing agricultural production in the Mediterranean region during the 18 th and 19th centuries were strongly dependent on the adequate replenishment of soil fertility. The low net primary production of Mediterranean agroecosystems reduced the chances of having plentiful livestock and, therefore, enough organic matter to replenish all the nutrients harvested. Under these conditions, the soil fertility of a significant portion of the agricultural land had to be replaced by natural means, that is, through fallow. Both production of manure and fallow required a significant proportion of land (i.e., high land cost; Guzmán Casado \& González de Molina, 2009) that had to be "paid for" by agricultural systems based on organic fertilization, especially in the Mediterranean region. As a consequence of this land cost, overall productivity per unit surface area was relatively low. Therefore, soil fertility was the major limiting factor for the development of Mediterranean agriculture, especially when the rural and urban population grew. This led to relative stagnation of land productivity and might have contributed to the so-named fin de siécle crisis ${ }^{2}$ (Abel, 1980; Williamson, 2006). To corroborate this hypothesis, we studied soil fertilization techniques in southern European farming systems throughout the 18th and 19th centuries, immediately preceding the extensive use of synthetic chemical fertilizers. This paper also shows the usefulness of nutrient balance tools applied to history.

\section{Materials and methods}

\section{Description of the three case studies}

Three case studies representative of three inland regions of Andalusia (southern Spain), but with different degrees of isolation, were selected: Montefrío (Granada), Baena (Córdoba), and Castilleja de la Cuesta (Sevilla) (Figure 1, web link). ${ }^{3}$

Baena covers an area of $420 \mathrm{~km}^{2}$ of rugged terrain in Guadalquivir Valley. The climate is continental with average annual rainfall and potential evapotranspiration (PET) of $641 \mathrm{~mm}$ and 1,378 mm, respectively. Montefrío $\left(254 \mathrm{~km}^{2}\right)$ is situated in the central sector of the Baetic system, northwest of the province of Granada. The climate is Mediterranean-continental, with annual rainfall similar to that of Baena, $654 \mathrm{~mm}$, but with considerably lower PET $(760 \mathrm{~mm})$. The main feature of the Montefrío landscape is that the gradient

2 The fin de siécle crisis, which lasted from the end of the 19th century up to World War I, was caused by massive imports of cheap cereal from the United States and other non-European countries, leading to the "first globalization" of food markets (Abel, 1980; Williamson, 2006).

3 For map, see www.historiambiental.org/descarga-de-datos/nutrient-balances-and-management-of-soilfertility-prior-to-the-arrival-of-chemical-fertilizers-in-andalusia-southern-spain-human-ecology-review/. 
of most of the territory is more than $10 \%$. Agriculture management is typical of medium-mountain regions. Finally, Castilleja de la Cuesta is situated in the western sector of Seville province, $5 \mathrm{~km}$ from the city of Seville. It has a surface area of just $2.23 \mathrm{~km}^{2}$ spread over a small plateau near the right bank of the Guadalquivir River. The climate is Mediterranean with oceanic influences and has an average annual rainfall of $574 \mathrm{~mm}$ and PET of 1,392 $\mathrm{mm}$. The gradient of most of the territory is less than $7 \%$ and only $16 \%$ has gradients of between $7 \%$ and $15 \%$.

Both Castilleja de la Cuesta and Montefrío were predominantly farmed by small peasant owners during the 18th and 19th centuries. Baena, however, was characterized by the predominance of large farms (latifundios), and cultivation was mainly rented out during this period. In the period studied, Montefrío was a relatively isolated area, with limited possibilities of exchanging energy and materials with the outside world so that agricultural expansion was highly dependent on domestic demand. In contrast, Castilleja de la Cuesta was heavily linked not only to national demand but also to the American market due its proximity to the Seville River port. A significant portion of its production was sold outside its territory. Finally, Baena was in an intermediate position and part of its production was sold elsewhere thanks to the proximity of the rail network, although the possibility for exchange was more limited than in the case of Castilleja de la Cuesta.

Three periods of study were selected according to their importance in the socioecological transition and the reliability of historical sources. These periods have been chosen to show the situation before the changes which led to liberalism (1752), that which might show the consequences of these changes (1856) and, finally, the period of the fin-de-siècle crisis (1897-1904), which we identify as the turning point in the transition process to agricultural industrialization.

\section{Data sources}

To assess land-use changes, population, livestock numbers, manure production, and yields for the different periods, for 1752 The Ensenada Cadastre was used as a source, both the General and Specific Responses. For the 19th century we used Amillaramientos de la Riqueza Rústica (similar to a land register for the payment of land taxes), Cartillas Evaluatorias (assessment notebooks), and Trabajos Agronómicos de la Comisión Central de Evaluación y Catastro (agronomic reports by the Agrarian Advisory Board). All these sources are kept in the public archives of Castilleja de la Cuesta, Montefrío, and Baena. In addition, the notary documents included in the provincial historical records of Seville, Córdoba, and Granada were used. Finally, the wealth documents of the Servicio Agronómico Provincial (Provincial Agronomic Service, 1880-1916) were also analyzed. 
Data from the Instituto Geográfico y Estadístico (Geographic and Statistical Institute, 1871-1873), published in the Statistical Yearbook of Spain (1888) was taken into account to compare land uses and agrarian surface areas.

\section{Nutrient balances}

\section{Input analyses}

Nitrogen $(\mathrm{N})$, phosphorus $(\mathrm{P})$, and potassium $(\mathrm{K})$ balances were performed at two different scales: at crop or rotation scale to determine their level of sustainability through the observed variability in land use, and at an aggregate scale (whole territory) to test for the degree of sustainability of the whole system.

$\mathrm{N}$, P, and $\mathrm{K}$ balances for both scales were determined using the methodology of García-Ruiz et al. (2011). Changes in state (from liquid to solid) and in form (from inorganic to organic) of $\mathrm{N}, \mathrm{P}$, and $\mathrm{K}$ already present in the agroecosystems were not considered to be input or output. In addition, dust-borne $\mathrm{N}, \mathrm{P}$, and K leaving the agroecosystems were not quantified, as we had no basic information to feed the model in order to estimate these inputs and outputs for the period 1752-1898. Nevertheless, the magnitude of these processes was probably low because most of the time soil was covered due to the very low population and working livestock which prevented a high tillage regime. $\mathrm{N}$ and $\mathrm{P}$ inputs via rainfall were calculated from the 100-year annual average of rainfall and the weighted annual average of total $\mathrm{N}$ and $\mathrm{P}$ analyzed in field rainwater collectors. Total $\mathrm{K}$ concentration in the rainwater was assumed to be $0.5 \mathrm{~g} / \mathrm{m}^{3}$, according to the annual grand mean value analyzed by Bellot and Escarre (1989) in rainwater for many sites of Spain. N, P, and K inputs via rainfall are negligible and therefore fixed to the type of crop or rotation or the periods of time considered.

The entries of $\mathrm{P}$ and $\mathrm{K}$ due to soil weathering were calculated from an estimate of the annual soil formation rate for Mediterranean regions and total $\mathrm{P}$ and $\mathrm{K}$ soil contents. Values differed for each crop or rotation according to the soil type in which they were cultivated.

Crop or rotation symbiotic $\mathrm{N}$ fixation were estimated from:

- amount of $\mathrm{N}$ harvested (based on historical information of the yield and an estimate of the grain and straw $\mathrm{N}$ content);

- amount of harvested $\mathrm{N}$ which came from the atmosphere (Gathumbi et al., 2002);

- amount of $\mathrm{N}$ in the root system (Wichern et al., 2008);

- amount of $\mathrm{N}$ in the root system which came from the atmosphere; and

- N rhizodeposition (Wichern et al., 2008). 
We adopted a value of $4 \mathrm{~kg} \mathrm{~N} / \mathrm{ha} / \mathrm{yr}$ for the atmospheric $\mathrm{N}$ fixed by free microorganisms, following the extensive literature review by Boring et al. (1988) covering a wide range of ecosystems. The influence of tillage for this entry was incorporated by reducing input according to the tillage regime and using a categorical scale.

The entries for $\mathrm{N}, \mathrm{P}$, and $\mathrm{K}$ via irrigation were calculated as the product of the irrigation water input $\left(\mathrm{m}^{3} / \mathrm{ha} / \mathrm{yr}\right)$ for each crop and the stream water concentration of $\mathrm{N}, \mathrm{P}$, and $\mathrm{K}\left(\mathrm{g} / \mathrm{m}^{3}\right)$ measured in unpolluted streams.

The annual inputs of N, P, and $\mathrm{K}$ through seed application for seeded crops such as wheat, barley, beans, and chickpeas were estimated from the annual seed application rates $(\mathrm{kg} / \mathrm{ha})$ taken from historical records and seed species' total $\mathrm{N}$, $\mathrm{P}$, and $\mathrm{K}$ content of traditional crops.

The amount of N, P, and $\mathrm{K}$ entering via organic fertilization was calculated from the annual dose of application ( $\mathrm{kg}$ fresh manure/ha/yr) for a given crop and the weighted mean of $\mathrm{N}, \mathrm{P}$, and $\mathrm{K}$ (kg element in fresh manure/kg of fresh manure) content in the manure. The weighted mean was calculated according to the livestock distribution in each period and the mean total $\mathrm{N}, \mathrm{P}$, and $\mathrm{K}$ in fresh manure.

In the balances, we did not consider the nutrients which might have been returned to the cropland by night soil as there were no statistics on the extent to which human-excreted N, P, and K were collected and where they were applied. Nevertheless, it is reasonable to assume that these nutrients were applied mainly to gardens for home consumption and/or to constant and occasional irrigation, and the ruedo crops which were usually located near the village center. Thus, nutrient inputs of these specific crops and inputs of the aggregate balances may have been underestimated. ${ }^{4}$

\section{Output analyses}

The main processes considered to quantify nutrient outputs were crop harvest, denitrification (only N), ammonia volatilization (only N), leaching (only N), and soil loss from erosion.

\footnotetext{
4 According to Del Porto and Steinfeld (1999), current annual N, P, and K human feces excretion ranges were $2.1-4.0 \mathrm{~kg} \mathrm{~N}, 0.3-0.6 \mathrm{~kg} \mathrm{P}$, and $1.0-2.0 \mathrm{~kg} \mathrm{~K}$, with lower values observed for poor countries in Africa and Asia. Discounting $\mathrm{N}$ losses by ammonia volatilization and leaching, and $\mathrm{P}$ and $\mathrm{K}$ by leaching during human feces storage and handling, and assuming all human-produced feces in Montefrío were applied, about 9.1, 14.2 and 18.1 tons of N-derived human feces would have been applied. These amounts would not have changed the sign of the balance (see Results and Discussion sections), nor the conclusions of this study. Magnitude of the N, P, and K recycled as human feces would have been much lower if we had assumed that only a proportion of the feces produced were collected and applied, and the child population considered.
} 
The annual depletion of $\mathrm{N}, \mathrm{P}$, and $\mathrm{K}$ by harvesting was assessed from the harvest (kg fresh harvest/ha/yr) of each crop and rotations and the contents of $\mathrm{N}, \mathrm{P}$, and $\mathrm{K}$ (on a wet basis) at harvest. Crop harvesting information was obtained from historical records and was therefore subject to change at different periods in time.

Farming basal $\mathrm{N}$ loss by denitrification was calculated using the model developed by Vinther and Hansen (2004), based on a combination of average values of $\mathrm{N}$ loss and manipulative experiment in field conditions. $\mathrm{N}$ loss by denitrification directly linked to organic fertilizer was assumed to be $2.5 \%$ of $\mathrm{N}$ applied as manure according to Kasimir Klemedtsson and Klemedtsson (2002). N loss through this process was basal loss plus that linked to fertilizer application rate, both of which were sensitive to crop and rotation.

Following the review of numerous studies by Holtan-Hartwig and Boeckman (1994), basal $\mathrm{N}$ loss by ammonium volatilization was assumed to be $1.5 \mathrm{~kg} \mathrm{~N} /$ ha/yr. As for denitrification, we calculated fertilized-based $\mathrm{N}$ volatilization as being $20 \%$ of that applied as manure following the European guide for emissions inventory (EEA, 1999).

To estimate $\mathrm{N}$ leaching we used the empirical model proposed by Di and Cameron (2000), which uses a quadratic function to relate the amount of $\mathrm{N}$ lost by leaching (per $100 \mathrm{~L} / \mathrm{m}^{2}$ of lixiviate) with the amount of potentially leachable nitrogen. In addition, the amount of potentially leachable nitrogen was calculated as the sum of all $\mathrm{N}$ inputs (rainfall, nitrogen fixation, irrigation, and input of organic fertilizer and seeds) minus the partial outputs (harvest, denitrification, ammonia volatilization, and erosion).

Annual N, P, and K losses by soil erosion were estimated based on the area occupied by the crops, the vegetation cover pattern of the crops, the current slope and landscape mapping of the area studied, and the current soil total N, P, and K. Annual soil loss was negligible for the irrigated croplands as they were located in plains with permanent or temporary streams. Cereals and rotations of cereals with legumes occupied small valley areas with low to moderate slopes and, therefore, the annual rate of soil loss would have been relatively small. Finally, olive groves and vineyards occupied less productive sites in areas of moderate to high slopes.

Nutrient balance aggregation (i.e., total nutrient balance for each locality) was calculated taking into account the nutrient balance for each single crop or rotation type and its area. 


\section{Results}

\section{Changes in land use, crop distribution, population, and livestock numbers}

The main features of the crops and rotations studied are summarized in Table 1. Table 2 shows the changes in land use for the three sites studied. From 1752 to 1897 cropland increased by $20 \%$ in Baena, more than doubled in Montefrío, but declined by $13 \%$ in Castilleja de la Cuesta. Irrigated crops accounted for a low percentage of cropland overall. Land for the ruedo rotation increased more than tenfold for Montefrío, nearly sixfold for Baena and occupied 22\% of the cropland area in Castilleja de la Cuesta. In Baena a modification of the ruedo, the trasruedo, appeared in the mid-19th century, reaching almost 5,000 ha at the end of the century. The one-third rotation decreased in Baena and Castilleja de la Cuesta but increased in Montefrío. Olive groves increased in the three sites to the 1850s and continued to increase only in Montefrío thereafter. Vineyards also increased significantly in Montefrío over 150 years but decreased in Baena and Castilleja de la Cuesta.

Table 1. Main characteristics of the major crops at the three sites, 1752-1897

\begin{tabular}{|l|l|}
\hline Crop/rotation & Main features \\
\hline Constant irrigation & $\begin{array}{l}\text { Vegetables and fibers harvested annually. Intensive management with } \\
\text { manure application. Crop found at all three sites. }\end{array}$ \\
\hline Occasional irrigation & $\begin{array}{l}\text { Annual crop of cereals, legumes, and vegetables. Very intensive } \\
\text { management, which included manure. Not used at Castilleja de la Cuesta. }\end{array}$ \\
\hline Ruedo & $\begin{array}{l}\text { 4-year rotation, alternating cereals with legumes. Medium-intensity } \\
\text { management which included some manure and at all three sites. }\end{array}$ \\
\hline Trasruedo & $\begin{array}{l}\text { 3-year rotation, alternating cereals with legumes. No manure application } \\
\text { and medium-intensity management. Used only at Baena. }\end{array}$ \\
\hline Año-y-vez & $\begin{array}{l}\text { 2-year rotation of wheat or barley alternating with fallow. Medium degree of } \\
\text { intensification, lacking manure. Used only at Baena. }\end{array}$ \\
\hline One-third rotation & $\begin{array}{l}\text { 3-year rotation of wheat or barley alternating with fallow. Not very intensive } \\
\text { and lacking manure. Found at all three sites. }\end{array}$ \\
\hline Olive groves & $\begin{array}{l}\text { Annual harvest of olives to produce olive oil, without manure and with very } \\
\text { low-intensity management. Found at all three sites. }\end{array}$ \\
\hline Vineyards & $\begin{array}{l}\text { Annual harvest of grapes to produce table grapes and wine, without manure } \\
\text { and with very low-intensity management. Found at all three sites. }\end{array}$ \\
\hline Fruit trees & $\begin{array}{l}\text { Annual harvest of fruit with medium degree of intensification and some } \\
\text { manure. Used only at Castilleja de la Cuesta. }\end{array}$ \\
\hline
\end{tabular}

Source: González de Molina (2002). 
Table 2. Land-use changes (hectares) in the three case studies, 1752-1897

\begin{tabular}{|l|r|r|r|r|r|r|r|r|r|}
\hline & \multicolumn{3}{|c|}{ Montefrí } & \multicolumn{3}{c|}{$\begin{array}{c}\text { Castilleja } \\
\text { de la Cuesta }\end{array}$} & \multicolumn{3}{c|}{ Baena } \\
\hline & 1752 & 1852 & 1897 & 1752 & 1854 & 1897 & 1752 & 1858 & 1897 \\
\hline $\begin{array}{l}\text { Constant } \\
\text { irrigation }\end{array}$ & 62.2 & 145.3 & 39.3 & 1.7 & 2.1 & 5.0 & 132.1 & 314.0 & 314.0 \\
\hline $\begin{array}{l}\text { Occasional } \\
\text { irrigation }\end{array}$ & 9.0 & 26.8 & 58.1 & - & - & - & 25.8 & 40.0 & 40.0 \\
\hline Ruedo & 24.2 & $1,324.3$ & $2,934.3$ & - & - & 36.4 & 588.9 & $3,267.9$ & $3,501.8$ \\
\hline Trasruedo & - & - & - & - & - & - & - & $3,618.1$ & $4,958.8$ \\
\hline Año-y-vez & - & - & - & - & - & - & $3,428.3$ & $2,666.7$ & $3,074.5$ \\
\hline $\begin{array}{l}\text { One-third } \\
\text { rotation }\end{array}$ & $7,348.0$ & $11,616.4$ & $12,311.0$ & 74.2 & 28.8 & - & $21,978.0$ & $17,673.6$ & $15,811.3$ \\
\hline Olive groves & 117.7 & 441.6 & 718.4 & 38.6 & 119.0 & 99.0 & $4,897.6$ & $9,912.0$ & $9,912.0$ \\
\hline Vineyards & 57.8 & 196.4 & 246.1 & 69.3 & 20.1 & 10.2 & $1,836.6$ & $1,569.0$ & $1,569.0$ \\
\hline Fruit trees & - & - & - & 6.8 & 31.0 & 14.9 & - & - & - \\
\hline Cropland & $7,618.9$ & $13,750.8$ & $16,307.2$ & 190.6 & 201.0 & 165.5 & $32,887.3$ & $39,061.3$ & $39,181.4$ \\
\hline Unproductive & $1,060.6$ & $1,060.6$ & $1,060.6$ & 32.5 & 21.9 & 57.4 & 480.0 & 480.0 & 480.0 \\
\hline Total area & 25,537 & 25,537 & 25,537 & 223 & 223 & 223 & 42,064 & 42,064 & 42,064 \\
\hline
\end{tabular}

Production increased by $68 \%$ in Baena, doubled in Castilleja de la Cuesta, and tripled in Montefrío (Table 3). Productivity increased by around $40 \%$ in both Montefrío and Baena, and by $130 \%$ in Castilleja de la Cuesta. Population roughly doubled for all three sites across the 150 years studied (Table 3).

Total livestock numbers reduced between 1752 and 1897 in Baena and Montefrío (Table 3), but remained about the same in Castilleja de la Cuesta. At the end of the 19th century, livestock numbers in Baena and Montefrío were $35 \%$ and $14 \%$ of what they were in the mid-18th century. The reduction was greater for revenue-producing livestock (sheep, goats, and pigs) and much lower for working animals (cattle, horses, donkeys, and mules). There was also a net reduction in the fertilization capacity (i.e., manure production) for Montefrío and Baena, although it remained almost unchanged in Castilleja de la Cuesta. 


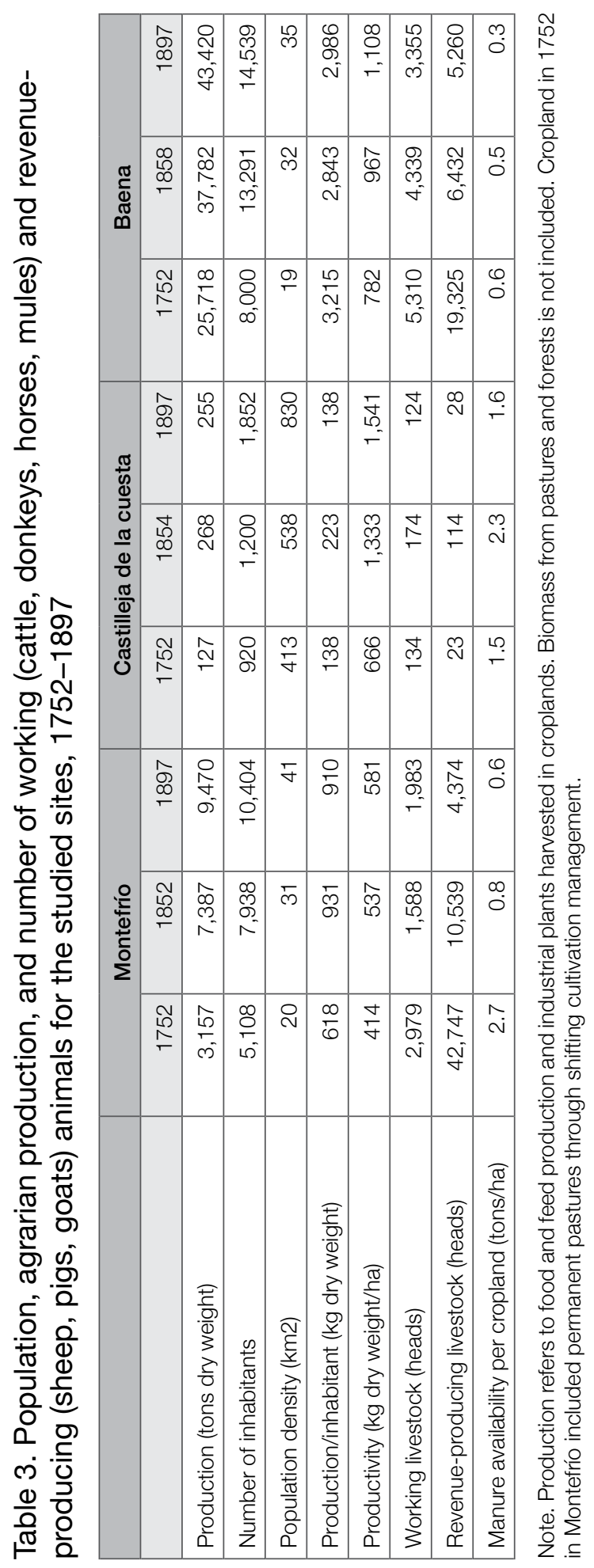




\section{Nutrient balances}

Tables 4, 5, and 6 show the N, P, and $\mathrm{K}$ balances for the periods studied for Castilleja de la Cuesta, Montefrío, and Baena, respectively. Irrigated vegetables showed a negative balance for $\mathrm{N}$ in Castilleja de la Cuesta and Montefrío during the 1750-1850 period, mainly because they were not fertilized, although productivity was quite high and comparable to that of the late 19th century when historical sources explicitly recorded organic fertilization. The occasional irrigated biennial rotation of beans and wheat showed a positive balance for $\mathrm{N}$ throughout the period studied, except for Baena late in the 19th century. The $\mathrm{N}$ balance for the four-year rotation (ruedo) of beans-wheat-chickpeaswheat for Baena was more negative throughout the 19th century, but changed from negative to positive in Montefrío. The one-third rotation showed a negative balance for Castilleja de la Cuesta, was slightly negative for Baena, and slightly positive for Montefrío. There was no clear temporal trend for Baena and Montefrío, whereas the balance was more negative throughout the 19th century in Castilleja de la Cuesta. The año-y-vez rotation, exclusive to Baena, showed a negative balance for $\mathrm{N}$, without any major changes over time. The $\mathrm{N}$ balance for olive groves and fruit trees was positive for the three sites, except for Baena in the late 19th century. Finally, the balance for vineyards was negative for all three sites, and during the periods studied the magnitude of the negative balance increased in Baena, remained unchanged in Montefrío, and decreased in Castilleja de la Cuesta due to organic fertilization in the late 19th century.

$\mathrm{P}$ and $\mathrm{K}$ balances for crops in Castilleja de la Cuesta were negative (Table 4) due to the decrease in the manure application rate, except for constantly irrigated vegetables and $P$ in vineyards at the end of the 19th century. Generally, the magnitude of the negative balance increased slightly throughout the period studied. The negative balance for K was, in general, higher than that for P.

Table 4. Net balances of nitrogen, phosphorus, and potassium (kg element/ha/yr) for Castilleja de la Cuesta, 1752-1897

\begin{tabular}{|l|r|r|r|r|r|r|}
\hline & Constant irrigation & One-third rotation & Olive groves & Vineyards & Fruit trees \\
\hline \multicolumn{7}{|l|}{ Nitrogen (N) } \\
\hline 1752 & -25.7 & -0.5 & 12.0 & -5.9 & 14.7 \\
\hline 1854 & -32.6 & -4.6 & 4.0 & -16.6 & 10.7 \\
\hline 1897 & 33.9 & -17.6 & 7.3 & -0.1 & - \\
\hline Phosphorus (P) & & & & & \\
\hline 1752 & -16.3 & -1.1 & -0.9 & 0.7 & -0.6 \\
\hline 1854 & -16.9 & -2.7 & -2.1 & -3.4 & -1.2 \\
\hline 1897 & 8.3 & -5.8 & -1.6 & 3.5 & - \\
\hline
\end{tabular}




\begin{tabular}{|l|r|r|r|r|r|}
\hline & Constant irrigation & One-third rotation & Olive groves & Vineyards & Fruit trees \\
\hline Potassium $(K)$ \\
\hline 1752 & -29.7 & -12.9 & -15.8 & -13.7 & -12.7 \\
\hline 1854 & -30.2 & -19.5 & -20.8 & -35.4 & -22.5 \\
\hline 1897 & 46.2 & -39.4 & -21.4 & -22.1 & - \\
\hline
\end{tabular}

Note. "-" means that a crop or rotation did not exist for this period.

Table 5. Net balances of nitrogen, phosphorus, and potassium (kg element/ha/yr) for Montefrío, 1752-1897

\begin{tabular}{|c|c|c|c|c|c|c|}
\hline & $\begin{array}{l}\text { Constant } \\
\text { irrigation }\end{array}$ & $\begin{array}{c}\text { Occasional } \\
\text { irrigation }\end{array}$ & Ruedo & $\begin{array}{l}\text { One-third } \\
\text { rotation }\end{array}$ & Olive groves & Vineyards \\
\hline \multicolumn{7}{|c|}{ Nitrogen (N) } \\
\hline 1752 & -13.6 & 7.8 & -3.6 & 0.7 & 15.2 & -3.7 \\
\hline 1852 & -6.0 & 5.0 & 6.2 & 5.0 & 5.5 & -8.9 \\
\hline 1897 & 6.1 & - & 2.1 & 0.1 & 4.3 & -8.9 \\
\hline \multicolumn{7}{|c|}{ Phosphorus (P) } \\
\hline 1752 & -3.1 & 2.6 & 0.8 & -0.6 & -1.2 & -1.1 \\
\hline 1852 & -1.2 & 1.9 & -0.2 & -1.5 & -2.7 & -3.4 \\
\hline 1897 & 3.6 & - & -0.4 & -1.4 & -2.9 & -3.5 \\
\hline \multicolumn{7}{|c|}{ Potassium (K) } \\
\hline 1752 & 9.1 & 18.0 & -5.3 & -12.1 & -27.8 & -23.2 \\
\hline 1852 & 13.0 & 7.1 & -7.4 & -17.2 & -53.2 & -53.4 \\
\hline 1897 & 29.9 & - & -12.8 & -17.2 & -54.1 & -53.4 \\
\hline
\end{tabular}

Note. "-" means that a crop or rotation did not exist for this period.

Table 6. Net balances of nitrogen, phosphorus, and potassium (kg element/ha/yr) for Baena, 1752-1897

\begin{tabular}{|c|c|c|c|c|c|c|c|c|}
\hline & $\begin{array}{l}\text { Constant } \\
\text { irrigation }\end{array}$ & $\begin{array}{c}\text { Occasional } \\
\text { irrigation }\end{array}$ & Ruedo & Trasruedo & $\begin{array}{c}\text { Año- } \\
\text { y-vez } \\
\text { rotation }\end{array}$ & $\begin{array}{l}\text { One- } \\
\text { third } \\
\text { rotation }\end{array}$ & $\begin{array}{l}\text { Olive } \\
\text { groves }\end{array}$ & Vineyards \\
\hline \multicolumn{9}{|c|}{ Nitrogen $(\mathrm{N})$} \\
\hline 1752 & -1.33 & - & 1.2 & - & -3.3 & -0.3 & 0.7 & -7.1 \\
\hline 1858 & 9.79 & 2.98 & -4.7 & -4.4 & -2.9 & 1.5 & 0.3 & -9.1 \\
\hline 1897 & -7.78 & -1.96 & -9.8 & -4.4 & -3.4 & -0.9 & -3.4 & -16.8 \\
\hline \multicolumn{9}{|c|}{ Phosphorus (P) } \\
\hline 1752 & 1.74 & - & 3.6 & - & -2.4 & -1.5 & -2.8 & -1.5 \\
\hline 1858 & -12.40 & -2.25 & 0.1 & -1.3 & -2.9 & -1.6 & -2.8 & -2.0 \\
\hline 1897 & -3.26 & 6.91 & -2.1 & -1.3 & -3.3 & -2.1 & -3.4 & -3.5 \\
\hline
\end{tabular}




\begin{tabular}{|l|r|r|r|r|r|r|r|r|}
\hline & $\begin{array}{l}\text { Constant } \\
\text { irrigation }\end{array}$ & $\begin{array}{c}\text { Occasional } \\
\text { irrigation }\end{array}$ & Ruedo & Trasruedo & $\begin{array}{c}\text { Año- } \\
\text { y-vez } \\
\text { rotation }\end{array}$ & $\begin{array}{c}\text { One- } \\
\text { third } \\
\text { rotation }\end{array}$ & $\begin{array}{c}\text { Olive } \\
\text { groves }\end{array}$ & Vineyards \\
\hline
\end{tabular}

Note. "-" means that a crop or rotation did not exist for this period.

In Montefrío, the ruedo, one-third rotation, olive groves, and vineyards all showed negative balances for $\mathrm{P}$ and $\mathrm{K}$, which increased throughout the 19th century (Table 5). As occurred in Castilleja de la Cuesta, only irrigated cropland achieved positive balances for both nutrients. Similar trends were observed for Baena. $\mathrm{P}$ and $\mathrm{K}$ balances for all rotations and woody cropland were negative and tended to be more negative during the 19th century, whereas the balance was positive for irrigated cropland from the mid-19th century onwards.

To relate the magnitude of the negative balances to long-term crop sustainability, the time in which a reduction of the annual soil availability of $\mathrm{N}, \mathrm{P}$, and $\mathrm{K}$ due to that negative balance equaled the crop annual demand for $\mathrm{N}, \mathrm{P}$, and $\mathrm{K}$ was calculated only for Montefrío. For historical long-standing crops such as ruedos and one-third rotations, more than 500 years were needed for the negative balances of $\mathrm{P}$ and $\mathrm{K}$ to affect the harvest. However, for olive groves and vineyards the number of years was less than 500 and decreased throughout the 19th century, so that woody crops were not sustainable in the long term (i.e., < 300 years) from the mid-19th century.

\section{Manure and nutrient aggregated balances}

In 1752, the quantity of manure applied was lower than that available for the three sites (Figure 2). However, all the available manure was used from the mid19th century onward for Baena and Montefrío. In Castilleja de la Cuesta, manure availability was higher than that used for the first two thirds of the 19th century but was closer to parity at the end of that century. 
Human Ecology Review, Volume 21, Number 2, 2015
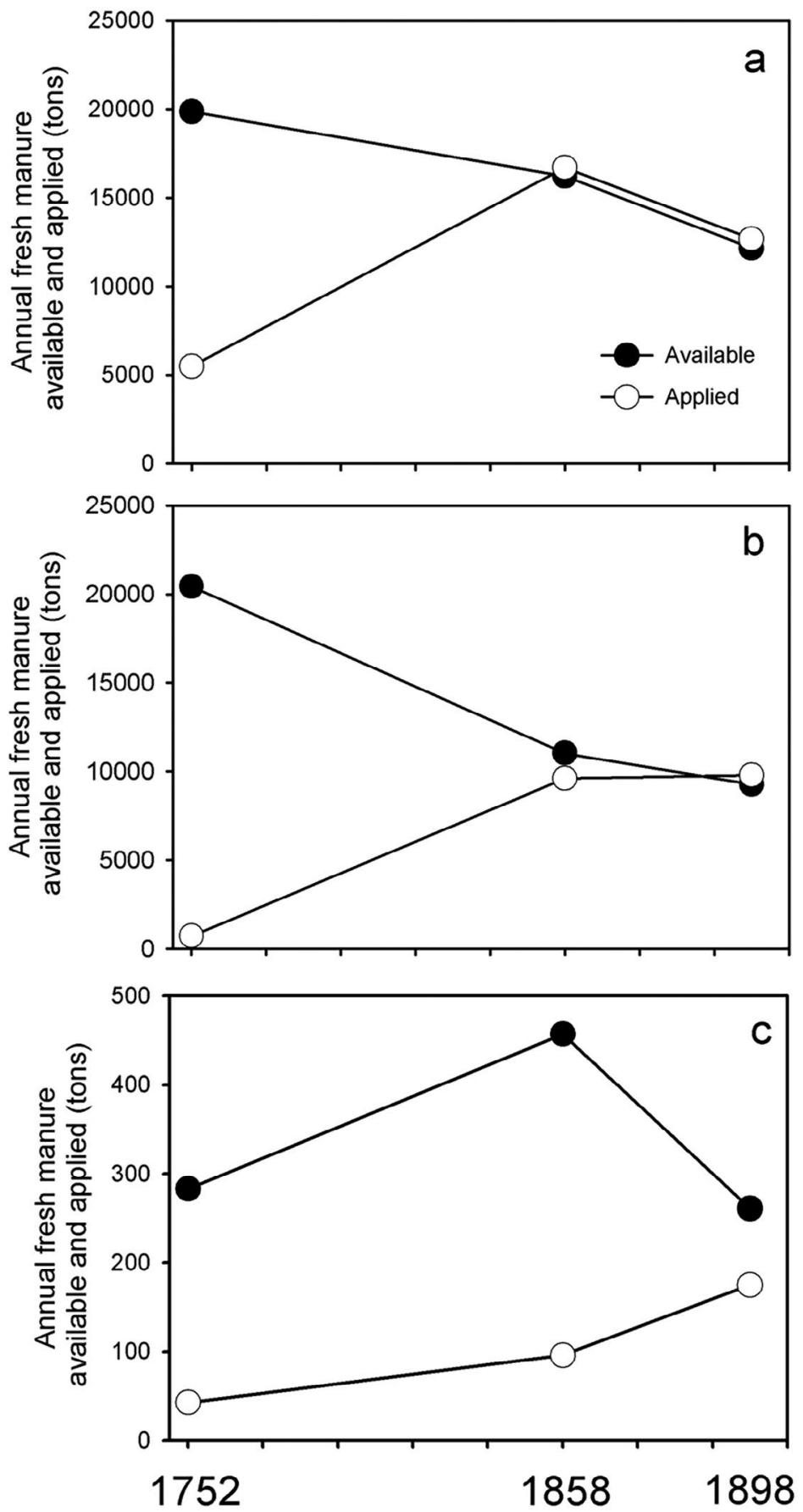

Figure 2. Annual fresh manure availability (full circles) and applied (empty circles) in (a) Montefrío, (b) Baena, and (c) Castilleja de la Cuesta, 1752-1897 
Changes in the aggregated net balances for N, P, and K are shown in Figure 3. For Baena and Montefrío, the aggregate $\mathrm{N}$ balance was positive for the period corresponding to 1752, and still positive in the mid-19th century in Castilleja de la Cuesta. However, from 1858 the aggregated balance for $\mathrm{N}$ was increasingly negative and by the end of the 19th century it accounted for an annual net loss of 150 tons and 15 tons of $\mathrm{N}$ for Montefrío and Baena, respectively.

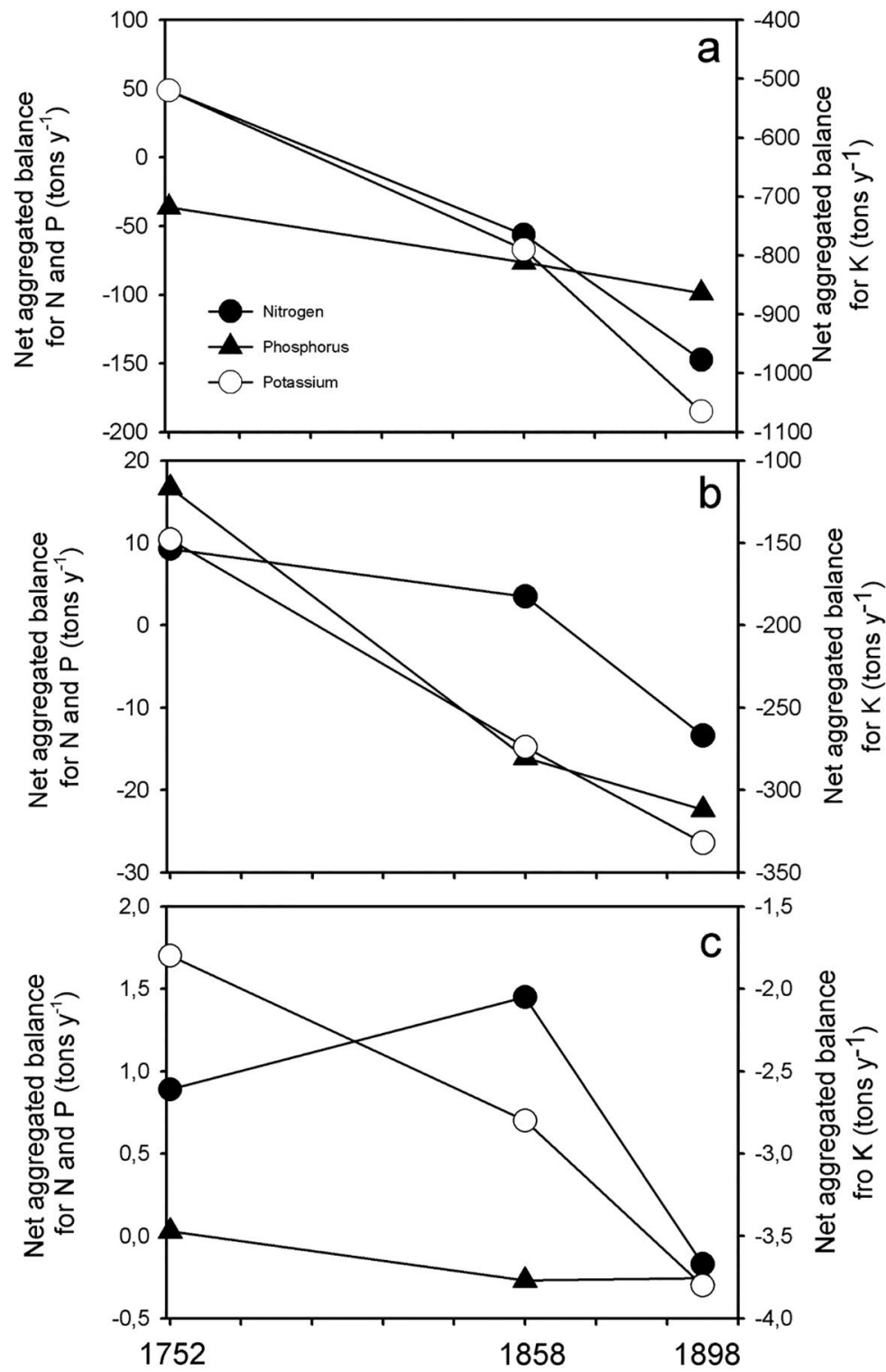

Figure 3. Aggregated net balance for nitrogen (full circles), phosphorus (full triangles) and potassium (empty circles) for (a) Montefrío, (b) Baena, and (c) Castilleja de la Cuesta, 1752-1897 
In Baena, the aggregated net balance for the three nutrients for the 1750-1900 period was markedly negative. A similar trend was observed for $\mathrm{N}$ and $\mathrm{K}$ in Montefrío, while the decline in $\mathrm{P}$ was less severe. In Castilleja de la Cuesta, $\mathrm{K}$ declined steadily, $\mathrm{P}$ remained relatively stable, and $\mathrm{N}$ declined significantly from 1858.

\section{Discussion}

\section{Changes in land use, production, and manure fertility capacity}

Between 1752 and 1897 both production and productivity increased markedly in the three sites (Table 3), indicating that the accepted idea in Spanish historiography that agriculture was developed extensively rather than intensively over this period (Llopis Agelán, 2004) should be viewed with caution. The increase in productivity only became possible through the expansion of irrigated areas and the extension of more intensive crop rotation. Therefore, the main strategy to increase productivity in the Mediterranean inland areas in the late 19th century was the combination of an increase in cropland extension and intensification, although the former was heavily restricted by the availability of labor and the latter by fertilizers.

The very low population density in Baena and Montefrío was probably the main reason for the low production and productivity in those sites in the 18th century. The availability of arable land or fertilizer did not seem to be limiting factors for production, although the shortage of manpower was. Indeed, a significant part of the arable land in Montefrío (96\%), Castilleja (39\%), and Baena (67\%) was devoted to non-fertilized cereal crops in a one-third rotation, characterized as subsistence crops. Fertilized intensive production, which took place during the 19th century, occupied relatively small areas. A combination of vegetables and fruits, and in some cases cereals, were the main crops grown intensively on irrigated land, together with the ruedo rotation, which was located in rainfed land near the villages, where the application of intensive work and fertilization was more feasible.

Population density steadily increased during the 19th century, probably due to the relative ease of cultivating new lands and the increased degree of specialization or intensification of areas already cultivated. Therefore, labor was no longer the main factor limiting production. The increase in population density had major socioeconomic and cultural consequences, and the land devoted to food was expanded at the expense of territory for feeding livestock. Revenue-producing livestock decreased significantly between 1752 and 1897 in 
Montefrío (90\%) and Baena (73\%), probably because these animals (sheep, pigs, and goats) used parts of the agroecosystem that could not then be used for human food production or working animals. The number of working animals did not fall as sharply, given the net increase in demand for animal traction and the increase in cultivated land. As a consequence of the overall loss of livestock, the availability of manure per cultivated hectare was consistently low (Table 3).

These results suggest that the very low increase in productivity from the middle to the end of the 19th century $(8 \%, 14 \%$, and $18 \%$ for Montefrío, Baena and Castilleja de la Cuesta, respectively) in the Mediterranean region was due to a decrease in organic fertilization capacity. The decline in agrarian production per capita (data not shown) could be explained by this fact. It seems clear that the imbalance between cultivated land and that dedicated to animal feed affected fertilization capacity at a time when large shipments of grain, straw, and manure were limited.

The potential development of agriculture practiced in the 19th century in the agroecosystems of these three sites representative of the Mediterranean inland was close to its limit in the last decade of the 19th century, as the possibilities of increasing cultivated land were very limited. In general terms, there was stagnation or even a reduction in yields, with the exception of the woody crops.

These considerations suggest that the aforementioned rise in production between the mid and late 19th century was only achieved at the expense of the pool of soil nutrients (i.e., soil mining). The generalized decline in the amount of available manure per hectare of cultivated land supports this idea.

\section{Changes in crop nutrient balances}

Results of the nutrient balances showed similar trends for the three sites. Crops or rotations with access to manure showed generally positive balances (i.e., surpluses of nutrients), and unfertilized areas tended to be negative, only lessened in the case of $\mathrm{N}$ by $\mathrm{N}$-fixing from legumes or weeds (olive groves and cereals in the fallow third). However, the magnitude was different for various crops or rotations with different significances from short-, medium-, and longterm viability of the crop. Crop types or rotations that included legumes and/or a year of fallow with natural weeds or woody crops with natural weeds for most of the year (such as olive and fruit groves) displayed a positive balance for $\mathrm{N}$.

As expected, nutrient balance for the irrigated land showed slight deficits or positive balances, given that most of the manure was applied to these crops. Occasional irrigation crops showed positive balances, mainly because these crops were rotated on a biennial basis with cereals and legumes. In this rotation model, legumes were a key element of $\mathrm{N}$ balance. 
Non-irrigated land was divided into three distinct parts following a concentric pattern. The territory near villages was used to grow cereals as the main subsistence crop. The one-third rotation, which changed slightly depending on the site and period, consisted of wheat, rest, and seeded fallow in a threeyear cycle and occupied significant arable land in Montefrío and Baena. The predominance of the one-third rotation was declining in Castilleja de la Cuesta and Baena as the agroecosystems specialized in woody crops, especially olive groves and the ruedos, but increased in Montefrío, probably because the uncultivated land was far from the useful area for crop production. The low population density in 1752 could explain the large scale and extensive nature of this system, generally poor in yield and associated with subsistence crops. The balance for $\mathrm{N}$ was near neutral for Montefrío and Baena but negative for Castilleja de la Cuesta. The balances for $\mathrm{P}$ and $\mathrm{K}$ were negative, strongly so for the latter. The harvest of this rotation was based on the removal (soil mining) of considerable amounts of $\mathrm{P}$ and $\mathrm{K}$ from the soil. This rotation, probably the consequence of a manure shortage which was resolved at the expense of a high land cost, displayed a negative balance for $\mathrm{P}$ and $\mathrm{K}$ from the very beginning. This situation must have been fairly common throughout the rainfed cereal lands of Andalusia with an equilibrated $\mathrm{N}$ balance, mainly due to the natural weed legumes in the year of rest, and significant deficits for $\mathrm{P}$ and $\mathrm{K}$. A rotation as widespread as this was only possible due to the soil's $\mathrm{P}$ and $\mathrm{K}$ reservoir, that is, through mining.

Another grain crop cultivated relatively near villages was the ruedo. In Montefrío, the ruedo, also fertilized, displayed negative-although not very significant - balances for $\mathrm{N}$ and $\mathrm{K}$ during the 1752 period, due to low intensification. The nutrient balances for Baena in this period were more equilibrated (positive or near zero), because of the contribution of the legumes together with relatively low yields and some manure. Throughout the 19th century, the balance became more negative in Baena and remained unchanged or even slightly positive in Montefrío due to the use of higher doses of manure (15 tons) in Montefrío, and because of the alternation of wheat with beans to the detriment of chickpeas (for human consumption only), which have a relatively limited symbiotic $\mathrm{N}$-fixation capacity. The $\mathrm{P}$ and $\mathrm{K}$ deficits were probably due to a shortage of manure, which, as we shall discuss later, affected arable land in the area. The rotation systems used in both municipalities combined cereals with legumes, thereby increasing inputs of $\mathrm{N}$ to the soil and food per unit area for both man and livestock. We believe that this rotation, which eliminated fallow due to the application of manure, represented the specific "agrarian revolution" of southern Spain and spearheaded the intensification of production experienced by Andalusia in the 19th century. In the mid-19th century, the specific agrarian revolution of southern Spain had demonstrated its benefits and this rotation was multiplied by 5.4, accounting for 3.268 ha in Baena. 
The existence only in Baena of the año-y-vez rotation model, which alternated wheat and barley without fertilization with fallow in the second year, can be explained by the increasing interest in intensification. Yields increased during the late 18th century to mid-19th century then remained unchanged until the late 19th century. Due to the lack of fertilization, this rotation could only be maintained following the constant removal of the reservoir of soil nutrients. Recognition of this mining is important because this rotation was believed to be the peasant alternative to the extensive one-third rotation of large farms in Andalusia, given their high labor intensity. We strongly believe that this rotation was not sustainable, at least in Baena. It also existed in Castilleja de la Cuesta, but required manure, which was severely limited by livestock numbers.

The rest of the rainfed land was used for woody crops including grapevines and olive groves. There is no record of any fertilization in any of the historic sources, except for grapevines in the late 19th century. Throughout the period studied, olive groves were becoming increasingly important. Both are representative of the edapho-climatic conditions of inland Andalusia, where specialization in woody crops gained importance during the 19th century, a prelude to the main productive orientation of the 20th century. During the 18th century the degree of intensification was generally fairly low but increased significantly from the mid-19th century. $\mathrm{N}$ balances were positive, probably as a result of natural weeds, which included forage legumes that contributed to the replenishment of $\mathrm{N}$ removed by harvesting and pruning. The balance for $\mathrm{P}$ and especially $\mathrm{K}$ registered significant net losses. The intensification of olive farming during the 19th century by increasing tree density not only increased the net extraction of soil $\mathrm{P}$ and $\mathrm{K}$, but meant that the balance for $\mathrm{N}$ was also less positive (in Montefrío) or even changed from positive to negative (in Baena).

Grapevines were important in the mid-18th century in Castilleja de la Cuesta and Baena but declined significantly throughout the 19th century. Over the same period in Montefrío, however, there was a fourfold increase in vineyard croplands. In general, yields increased significantly from the mid-18th century to the late 19th century. This clear intensification could only give rise to a significant deficit in the balances of $\mathrm{K}, \mathrm{P}$, and especially $\mathrm{N}$, since manure was not applied. Not surprisingly, the rise in yields in several decades at the end of the 19 th century was possible only through the application of a significant amount of manure (up to 32 tons) every five years. $\mathrm{N}$ balances were negative during the 18th and most of the 19th century, mainly because of the lack of natural weed cover with $\mathrm{N}$-fixation capacity. Phosphorus was negative and $\mathrm{K}$ balances strongly negative throughout the periods studied for the three sites, indicating that this form of cultivation was linked to soil nutrient mining, and as the 
intensification of crops increased, so did mining. There was a decrease in natural capital at the expense of vine exportation. The specialization of vineyards to produce table grapes was possible only through the application of manure.

\section{Significance of net nutrient extractions for long-term agrarian sustainability}

The significance of deficits is largely dependent on the type of rotation and nutrient concerned. $\mathrm{N}$ deficiencies usually limit productivity in the short term and affect crop yield sooner, as the only significant route of input is via the atmosphere. Furthermore, in addition to soil loss and yield there are other output processes, such as denitrification, ammonia volatilization, and $\mathrm{N}$ leaching, that do not apply to $\mathrm{P}$ and $\mathrm{K}$. In addition, $\mathrm{P}$ deficits had medium-term effects on yields because bedrock continuously supplied available $\mathrm{P}$ and soil has high P-retention capacity through complex processes. The amount of $\mathrm{P}$ taken up by crops is also much lower than $\mathrm{N}$. Negative balances for $\mathrm{K}$ can be viable in the long term even though harvested $\mathrm{K}$ is similar to $\mathrm{N}$, because the short-, medium-, and long-term pool of soil $\mathrm{K}$ available is usually vast.

In order to get an approximate idea of the consequences of such deficits, in the case of Montefrío, the number of years in which nutrient deficiencies affected crop yields (i.e., the number of years in which $\mathrm{N}, \mathrm{P}$, and $\mathrm{K}$ available in soil met crop demand for nutrients) were calculated (Table 7 , web link). ${ }^{5}$ Onethird cereal rotations or more intensive crops such as the ruedo in Montefrío, with net nutrient extractions, were nutrient sustainable ( $>500$ years, Table 7) from an agrarian point of view. However, for woody crops such as olives and especially vines, the period for which annual $\mathrm{P}$ and $\mathrm{K}$ available in soil was lower than nutrient removal (harvest) was shorter. For both crops, if chemical $\mathrm{P}$ and $\mathrm{K}$ had not been applied early in the 20th century, it is probable that symptoms of nutritional deficiencies would have appeared today or even earlier. The grapevine was the only crop in the three case studies which showed a clear negative balance for $\mathrm{N}$ (Tables 4-6). It was the only crop with no input of organic matter and no $\mathrm{N}$ input from atmospheric $\mathrm{N}$. As a consequence, the soil nitrogen pool progressively dwindled. The results clearly suggest that the vineyards of inland Spain can be considered unsustainable without the aid of fertilizers.

\section{The aggregate balance: Toward unsustainability}

One of the most important attributes that should be taken into account when measuring the sustainability of agricultural systems is stability. This roughly encompasses the long-term maintenance of an agroecosystem's net primary

5 Available at http://www.historiambiental.org/descarga-de-datos/nutrient-balances-and-management-ofsoil-fertility-prior-to-the-arrival-of-chemical-fertilizers-in-andalusia-southern-spain-human-ecology-review/. 
production. The territory had to maintain and even expand the aforementioned rotations - especially the most intensive ones - with its own resources, and this can be analyzed when aggregate balance is performed. This is particularly relevant for periods in the past, when importing nutrients from outside was heavily restricted and harnessing available biological energy required specific amounts of land (land cost) to replenish the harvested nutrients.

Around 1752, the availability of manure was enough to sustain crop demand, indicating that other factors, such as economics, led to an underutilization of abundant organic matter produced by livestock. The intensification of production that took place between the mid-18th and 19th centuries was possible through an increased use of manure. As a result, manure availability declined significantly. At some point in the mid-19th century, the maximum use of available manure was reached. Data clearly indicate that in the last few decades of the 19th century, all three territories had practically reached their limit for further crop intensification based on the resources of the agroecosystem. This fact might have contributed to the drop in yields and the negative balances of the three nutrients, despite the lower yields.

From a theoretical point of view, the presence of legumes in some rotations meant there was no shortage of $\mathrm{N}$ in either of the periods around 1752 or 1854 . However, this was not the case for $\mathrm{P}$, with slightly higher losses than inputs, and $\mathrm{K}$, with clear mining. When a territory specialized in fruit trees, olive groves, and grapevines, nutrient removal not compensated with manure was generalized for all nutrients. In Castilleja de la Cuesta, chemical fertilizers were essential to further progress in terms of crop intensification and specialization and also to maintain the productive effort achieved in previous decades. This circumstance is significant in the context of the fin-de-siècle crisis, just before the extended use of chemical fertilization in Spain, when European farmers were forced to further increase yields per unit of land in order to compete in the national and international food markets. The results for Baena and Montefrío(Figure 2) confirm the findings for Castilleja de la Cuesta: a decline in fertilization capacity over the time period studied, which was greater in Baena and Montefrío, probably due to the reduction of land allocated to livestock feed. As a consequence, the territorial balance previously maintained was broken. It was also found that, in the late 19th century, the three sites all reached maximum possible crop intensification with their own resources and available technology. In fact, the negative aggregated balance observed for 1897 in Montefrío reveals that this capacity had been exceeded and that without the aid of synthetic chemical fertilizers, the level of intensification had to be reduced.

The intensification of cereals and specialization in olive groves and vineyards were responsible for the deficit of nutrients. The net reduction in nutrient availability resulting from the decrease in livestock meant that intensification 
was based on the soil pool of nutrients (i.e., mining), especially for $\mathrm{P}$ and K. Even the effect of forage legumes in weed cover, which until the mid-19th century had made it possible to sustain a positive nitrogen balance, could not be maintained in subsequent years. The soil nutrient reservoir was key to increasing yields and maintaining productive efforts during the 19th century.

\section{Conclusions}

The extensive cropland, the presence of fallow, and the low yields can be interpreted as an adaptive strategy by farmers to the structural shortage of manure. Thus, nutrient extraction was minimal for crops and rotations that were not fertilized. Nevertheless, the increase in food demand meant that arable land for food had to be expanded at the expense of land used to produce animal feed, and in turn this led to a clear decline in livestock numbers and a net reduction in the capacity to fertilize. As a result, the possibilities for further crop intensification were severely limited. It is clear that the intensification of unfertilized crops and rotations was based on the extraction of nutrients from the soil reservoir.

During the final decades of the 19th century, the three sites studied had reached or were close to the upper limit in terms of their possibilities for further intensification of agrarian production. Human and livestock carrying capacities were exceeded for the three territories studied. For some crops where production increased, especially woody crops, this was only possible at the expense of the soil nutrient reservoir and it made them even more unsustainable in the medium to long term. The scope of these deficits contrasts with the sustainability of woody crop specialization, which has been proposed as a plausible strategy for agrarian growth during the 19th century. However, it was based on the export of natural capital. The fact that the expansion of land allocated to vineyards and olive groves was preferably made on uncultivated land with a virtually untouched reservoir of nutrients might explain why this phenomenon was not noticed until recently.

This study confirms that the replacement of soil fertility has become the key factor in the sustainability of agrarian metabolism based on solar energy. In addition, we firmly believe that this replacement played a key role in the start of the transition toward industrial metabolism in agriculture (Fischer-Kowalski \& Haberl, 2007). 


\section{Acknowledgments}

This investigation was possible thanks to the financial support from the Spanish Ministry for Education and Science (National R\&D\&i Programme HAR200913748-C03-03) for a project titled The Environmental History of Mediterranean Agrarian Landscapes, 1752-2008: A Contribution on Study of Socio-ecological Transition in Andalusia.

\section{References}

Abel, W. (1980). Agricultural fluctuations in Europe: From the thirteenth to the twentieth centuries. London: Methuen.

Allen, R. C. (2008). The nitrogen hypothesis and the English agricultural revolution: A biological analysis. Journal of Economic History, 68(1), 182-210.

Barles, S. (2007). Feeding the city: Food consumption and flow of nitrogen, Paris, 1801-1914. Science of the Total Environment, 375, 48-58.

Bellot, J., \& Escarre, A. (1989). Contribución del quimismo del agua de lluvia, de la deposición seca y la lixiviación, sobre la química de los flujos de trascolación y escorrentía cortical en el encinar mediterráneo. Options Méditerranéennes, $3,211-214$.

Boring, L. R., Swank, W. T., Waide, J. B., \& Henderson, G. S. (1988). Sources, fates, and impacts of nitrogen inputs to terrestrial ecosystems: Review and synthesis. Biogeochemistry, 6, 119-159.

Brassley, P. (2000). Plant nutrition. In J. Thirsk (Ed.), The agrarian history of England and Wales, VII, 1850-1914 (Part I, pp. 533-548). Cambridge: Cambridge University Press.

Campbell, B. M. S., \& Overton, M. (1991). Land, labour and livestock: Historical studies in European agricultural productivity. Manchester: Manchester University Press.

Cunfer, G. (2004). Manure matters on the Great Plains frontier. Journal of Interdisciplinary History, 34, 539-567.

Cunfer, G. (2005). On the Great Plains: Agriculture and environment. Texas: Texas A\&M University Press. 
Cunfer, G., \& Krausmann, F. (2013). Sustaining agricultural systems in the old and new worlds: A long-term socio-ecological comparison. In S. J. Sing, H. Haberl, M. Chertow, M. Mirtl, \& M. Schmidt (Eds.), Long term socioecological research: Studies in society-nature interactions across spatial and temporal scales (pp. 269-296). Berlin: Springer.

Del Porto, D., \& Steinfeld, C. (1999). The composting toilet system book. Concord, MA: The Center for Ecological Pollution Prevention.

Di, H. J., \& Cameron, K. C. (2000). Calculating nitrogen leaching losses and critical nitrogen application rates in dairy pasture systems using a semiempirical model. New Zealand Journal of Agricultural Research, 43, 139-147.

EEA (European Environment Agency). (1999). Atmospheric emission inventory guidebook (2nd ed.). Copenhagen: EMEP/CORINAIR.

Fischer-Kowalski, M., \& Haberl, H. (2007). Conceptualizing, observing and comparing socioecological transitions. In M. Fischer-Kowalski \& H. Haberl (Eds.), Socioecological transitions and global change (pp. 1-30). Cheltenham: Edward Elgar.

García-Ruiz, R., González de Molina, M., Guzmán, G., Soto, D., \& InfanteAmate, J. (2011). Guidelines for constructing nitrogen, phosphorus and potassium balances in historical agricultural systems. Journal of Sustainable Agriculture, 36, 650-682.

Gathumbi, S. M., Cadisch, G., \& Giller, K. E. (2002). ${ }^{15} \mathrm{~N}$ natural abundance as a tool for assessing $\mathrm{N}_{2}$-fixation of herbaceous, shrub and tree legumes in improved fallows. Soil Biology \& Biochemistry, 34(8), 1059-1071.

González de Molina, M. (2002). The environmental constraints on agricultural growth in 19th century Granada (southern Spain). Ecological Economics, 41, 257-270.

Guzmán Casado, G., \& González de Molina, M. (2009). Preindustrial agriculture versus organic agriculture: The land cost of sustainability. Land Use Policy, 26(2), 502-510.

Holtan-Hartwig, L., \& Boeckman, O. C. (1994). Ammonia exchange between crops and air. Norwegian Journal of Agricultural Sciences, (Suppl. 14).

Kasimir Klemedtsson, Å., \& Klemedtsson, L. (2002). A critical analysis of nitrous oxide emissions from animal manure. In S. O. Petersen \& J. E. Olesen (Eds.), Greenhouse gas inventories for agriculture in the Nordic countries (DIAS Report 81, pp. 107-121). Foulum, Denmark: Danish Institute of Agricultural Sciences. 
Krausmann, F. (2001). Land use and industrial modernization: an empirical analysis of human influence on the functioning of ecosystems in Austria 1830-1995. Land Use Policy, 18, 17-26.

Krausmann, F. (2004). Milk, manure and muscular power: Livestock and the industrialization of agriculture. Human Ecology, 32, 735-773.

Krausmann, F., Fischer-Kowalski, M., Schandl, H., \& Eisenmenger, N. (2008). The global sociometabolic transition: Past and present metabolic profiles and their future trajectories. Journal of Industrial Ecology, 12(5/6), 637-656.

Llopis Agelán, E. (2004). España, la revolución de los modernistas y el legado del Antiguo Régimen. In E. Llopis Agelán (Ed.), El legado económico del Antiguo Régimen en España (pp. 11-76). Barcelona: Crítica.

McNeill, J. R., \& Winiwarter, V. (Eds.). (2006). Soils and societies: Perspectives from environmental history. Isle of Harris: The White Horse Press.

Pfister, C. (1990). The early loss of ecological stability in an agrarian region. In P. Brimblecombe \& C. Pfister (Eds.), The silent countdown: Essays in European environmental history (pp. 37-55). Berlin: Springer.

Pimentel, D., \& Pimentel, M. (1996). Food, energy and society. Niwot, CO: University Press of Colorado.

Shiel, R. S. (2006). Nutrient flows in pre-modern agriculture in Europe. In J. R. McNeill \& V. Winiwarter (Eds.), Soils and societies: Perspectives from environmental history (pp. 216-242). Isle of Harris: The White Horse Press.

Sieferle, R. P. (2001). The subterranean forest: Energy systems and the industrial revolution. Cambridge, UK: The White Horse Press.

Smil, V. (2001). Enriching the earth: Fritz Haber, Carl Bosch and the transformation of world food production. Cambridge, MA: The MIT Press.

Smil, V. (2008). Energy in nature and society: General energetics of complex systems. Cambridge, MA: The MIT Press.

Tello, E., Garrabou, R., Cussó, X., Olarieta, J. R., \& Galán, E. (2012). Fertilizing methods and nutrient balance at the end of traditional organic agriculture in the Mediterranean bioregion: Catalonia (Spain) in the 1860s. Human Ecology, 40, 369-383.

Van Zanden, J. L. (1991). The first green revolution: The growth of production and productivity in European agriculture, 1870-1914. Economic History Review, 2, 215-239. 
Vinther, F. P., \& Hansen, S. (2004). SimDen - A simple empirical model for quantification of $\mathrm{N}_{2} \mathrm{O}$ emission and denitrification (DIAS Report 104, pp. 1-47). Foulum, Denmark: Danish Institute of Agricultural Sciences.

Wichern, F., Eberhardt, E., Mayer, J., Joergensen, R. G., \& Müller, T. (2008). Nitrogen rhizodeposition in agricultural crops: Methods, estimates and future prospects. Soil Biology \& Biochemistry, 40(1), 30-48.

Williamson, J. G. (2006). Globalization and the poor periphery before 1950. Cambridge, MA: The MIT Press. 
This text is taken from Human Ecology Review, Volume 21, Number 2, 2015, published 2015 by ANU Press, The Australian National University, Canberra, Australia. 